\title{
Leveraging the Power of Mobile Technology to Enhance ESP Students' Listening Comprehension
}

\author{
Ability \\ Dr. Yu-Chun Wang \\ Language Education Center, National Kaohsiung University of Science and Technology \\ 415 Jiangong Rd., Sanmin Dist. Kaohsiung 807, Taiwan \\ Tel: 886-7-381-4526 E-mail: willlie_wang@nkust.edu.tw \\ Received: May 15, 2019 Accepted: June 14, 2019 Published: June 16, 2019 \\ doi:10.5296/ijele.v7i1.14934 URL: https://doi.org/10.5296/ijele.v7i1.14934
}

\begin{abstract}
The ubiquitous nature of mobile devices and the expanding array of mobile learning applications enable the foreign language acquisition to take place outside the traditional classroom environment. This study conducted a mobile-assisted instructional experiment where the design and development of a mobile application were accomplished to serve students with diverse learning needs in a business English communication class, and with special emphasis on the practice and improvement of listening skills. The instruments used in this study include two tests, weekly quizzes and an attitude survey. The findings demonstrated positive effects of the mobile learning on ESP students with regards to their listening comprehension. Most of the students enjoyed having access to the mobile materials specifically designed to improve their learning performance. They perceived such technology-enhanced learning as a practical method for acquiring foreign language skills, because it provided them with an opportunity to accomplish learning tasks anywhere and at any time.
\end{abstract}

Keywords: mobile-assisted language learning (MALL), mobile apps; English for specific purposes (ESP), ubiquitous learning, listening comprehension 


\section{Introduction}

Listening is a critical receptive skill to develop in terms of foreign language acquisition. Without listening skills, language learning is impossible. This is because listening is important for effective communication and interpersonal interactions, and it was found that most people receive messages more quickly and efficiently via listening than reading (Luo, 2008). In spite of its importance in language learning, foreign language learners often regard listening as the most difficult communication skill to learn. As noted by Chen (2007), students study English as a foreign language (EFL) primarily through formal instruction in the classroom, with very little exposure to practical English education beyond formal study. This has forced them to contend with many challenges such as limited exposure to vocabularies, strange and foreign accents, and rapid speech. Thornton and Houser (2005) indicated that EFL students must constantly listen to and practice the language to become proficient in their learning performance. However, listening skills are not often specifically taught in schools. These skills are less focused and, so, have received less explicit attention (Moyer, 2006).The wide and accelerating use of multimedia technologies has made it both possible and easy to utilize mobile technology for providing students with flexible learning alternatives and interactive enhancements outside the classroom setting (Kukulska-Hulme \& Shield, 2008). In Taiwan, as in most EFL settings, many students do not seem to take advantage of the opportunities for practice being afforded by mobile devices and there is a general reluctance to seek out ways of learning the English language outside the formal classroom environment. Many college graduates still have difficulties understanding spoken English in a variety of business situations. Thus, the purpose of this study was to assess the utility of mobile devices in improving the listening comprehension of English for specific purposes (ESP) undergraduate students, especially in informal settings outside of the classroom.

\section{Literature Review}

\section{Listening as a Language Skill}

Listening is recognized as a critical skill in language learning and communication (Rubin, 1994), and occupies over 50 percent of the time a language learner spends functioning in a foreign language (Nunan, 1998). Many researchers believe that listening is a primary means of acquiring a second language (Nation \& Newton, 2009) because it provides input for the learner. Without comprehending input clearly, any language learning simply cannot begin (Rost, 1994). Although the importance of aural skills has been acknowledged, listening remains the least researched skill in language learning literature (Nation \& Newton, 2009). There are two distinct processes involved in listening comprehension. The top-down processing model refers to that the listener actively reconstructs the original meaning of the speaker using prior knowledge as clues (Richards \& Renandya, 2002) whereas the bottom-up processing assumes that the listener uses linguistic knowledge to understand the meaning of a message (Nunan, 2002). Recent research views listening as an active process requiring conscious attention and involvement (Rost, 2001). Lynch \& Mendelsohn (2002) revealed that the listener interprets and constructs meaning based on context and through interaction with 
interlocutors. Rubin (1994) suggested that for listening to be learned successfully, the following components should be integrated within a relevant context; learners' interaction with oral input, interlocutor, task listener, and process. When reviewing more specific features of listening material design, consideration should be also given to the issue of listeners' control of the speech rate as well as the affective factors including listeners' anxiety and self-confidence levels. For effective listening comprehension to ensure, the learner must not feel anxious or threatened by the situation (Krashen, 1981).

\section{Mobile-Assisted Language Learning (MALL)}

Mobile technologies are spreading quickly, providing increasing capacity, and thus enabling more sophisticated use. This influences cultural practices and opens up new avenues for learning (Reinders, 2010). Mobile learning is a method of delivering learning materials through the use of mobile technologies such as mobile devices and wireless networks (Wang, $\mathrm{Wu}, \&$ Wang, 2009). The characteristics of mobile learning include convenience, spontaneity, social interactivity, and portability (Peng et al., 2009). Valk, Rashid, and Elder (2010) found mobile learning to be a competent method of enhancing educational outcomes, because it improves access to information resources, promotes independent learning, and develops professional skills. According to Chinnery (2006), mobile learning can also be personalized, situational, and collaborative. It also offers students increased flexibility and new opportunities for ubiquitous learning. Although mobile learning provides many advantages, there are also drawbacks that need to be considered. For example, its dependence on networks may not always assure a high transmission capacity and may experience interruptions. Furthermore, mobile handheld devices have small screen sizes, which limit the presentation of information (Lan, Sung, \& Chang, 2007). Despite these drawbacks, Chen (2013) demonstrated that mobile technologies could be effective tools in delivering materials to students. His study showed that using mobile devices assists students by producing improved engagement with the learning and better interactions. As a subarea of the expanding field of mobile learning research, mobile-assisted language learning (MALL) has increasingly attracted the attention of scholars. MALL is described as an approach to language learning that is assisted by handheld mobile devices (Lan, Sung, \& Chang, 2007). It is also a computer-assisted language learning subset, which aids students in accessing language learning materials and in interacting with their teachers and fellow students, anywhere and at any time (Hsu et al., 2013). The recent study by Miangah and Nezarat (2012) revealed that learners can apply MALL to learn listening comprehension, reading comprehension, pronunciation, vocabulary, and grammar. Through mobile participation in short exercises and tasks, the students were able to retain their linguistic skills.

\section{MALL in Foreign Language Acquisition}

Over the past decade, a rising numbers of MALL studies have been devoted to the acquisition of foreign languages. The results of such learning have been remarkable (Chang \& Hsu, 2011; Chen \& Chung, 2008; Wang, Zou, \& Xing, 2014). One study illustrated how students were encouraged to use mobile phones to access video clips explaining English idioms (Thornton $\&$ Houser, 2005). This is one obvious example in the new trend that students are spending 
more time using mobile devices to perform learning activities. Another study found that those learning languages expressed positive attitudes towards the utilization of mobile phones for this purpose, and the results indicated that such activities had a positive effect on student-centered learning, as well as being an effective way of developing listening skills (Nah, White, \& Sussex, 2008). Moreover, Lan et al. (2007) found that using a mobile-device-supported peer-assisted learning system to aid EFL learning activities improved the collaboration among elementary school students and promoted their reading motivation. Baleghizadeh and Oladrostam (2010) also found that students who had benefited from mobile-assisted learning achieved higher levels of grammatical competence than did those who learned grammar without the support of mobile devices. Using PDAs as a support tool, Chen and Chung (2008) designed a personalized English vocabulary learning system. The system was anchored on item response theory and the learning memory cycle. The study showed that using a mobile adaptive English vocabulary learning system significantly improved students' vocabulary achievements. Additionally, Thornton and Houser (2005) investigated the use of email via mobile phones for learning English vocabulary. They found that using mobile phones to send English vocabulary to students effectively helped them to acquire knowledge. It can therefore be concluded that mobile learning can effectively accelerate vocabulary acquisition and provide motivation for learning the English language.

\section{Mobile Apps for Language Learning}

Application software, also known as apps, is computer software designed to help the users to perform singular or multiple related specific tasks (Franklin, 2011). A mobile application (app) is application software designed to run on smartphones, tablet computers or other mobile devices. Mobile apps were originally offered for general productivity and information retrieval including e-mail, calendars, contacts, stock market, and weather information. However, public demand and ease of app development has resulted in a variety of mobile app categories. According to Statista (2013), educational apps are the second most popular app category in the Apple Store. The data indicates that apps provide learning opportunities for users. Educational apps allow learners to have more interactions during the learning process. Falloon (2013) indicated that app design and content may influence students' learning pathways. They are important elements when considering the use of apps in education. Moreover, apps can encourage learners to engage in the learning process and motivate learning interest. For instance, Li and Hegelheimer (2013) applied MALL in second language undergraduate writing class and developed a mobile app called "Grammar Clinic" that included 15 common grammatical error types. Students were required to identify the grammar error, selecting an error type from four options, correct it, and then the system would provide student scores and feedback. The result showed that the percentage of identified and correct grammar errors increased. Students held positive attitudes toward using apps and considered the MALL App to be a convenient and easy to operate tool for language learning. These studies suggested that MALL has great potential for providing students with real-time interactive and shared media-rich experiences, both in and outside the classroom. However, the focus of MALL is primarily on reading (Chang \& Hsu, 2011; Lan et al., 2007), vocabulary (Chen \& Chung, 2008; Zhang, Song, \& Huang, 2014), and grammar 


\section{Macrothink Institute ${ }^{\mathrm{TM}}$}

(Baleghizadeh \& Oladrostam, 2010), rather than listening skills. Considering the limited number of MALL studies focused on ESP listening-skills training, this study conducted a MALL instructional experiment, in which a MALL App was designed and developed to assist EFL students in acquiring listening skills. The aim was to develop a better instrument for business English instruction.

\section{Materials and Methods}

Design of the MALLApp

A MALL App called "Business English Conversation: Essential Practices" was designed and developed through collaboration between university research and an educational technology development company to serve students with diverse learning needs in a business English communication class. It is available from the Apple App Store as a download on all Apple iOS devices. The MALL App includes a wide variety of business dialogues, translation support tool, vocabularies with definitions, and practical tips related to the topics listed. The conversation was recorded by native English speakers, where the learner could practice his or her accent and speaking speed as if talking to real foreigners. As the learner listens to the conversation, he or she can also read the bilingual script to understand the content. The vocabulary part provides pronunciation, phonetic, speech, a glossary, and sentences for the learners. At the end of each section, the learner can check their level of understanding using the practice tests. By learning through this App, students can prepare for an interview in English and determine how to communicate with bosses, colleagues or customers and how to solve problems that are encountered in real life. The learning materials were primarily drawn from the course text book, Communicating in Business, Second Edition. Figures 1-3 are depictions of the content and activities inside the MALL App.

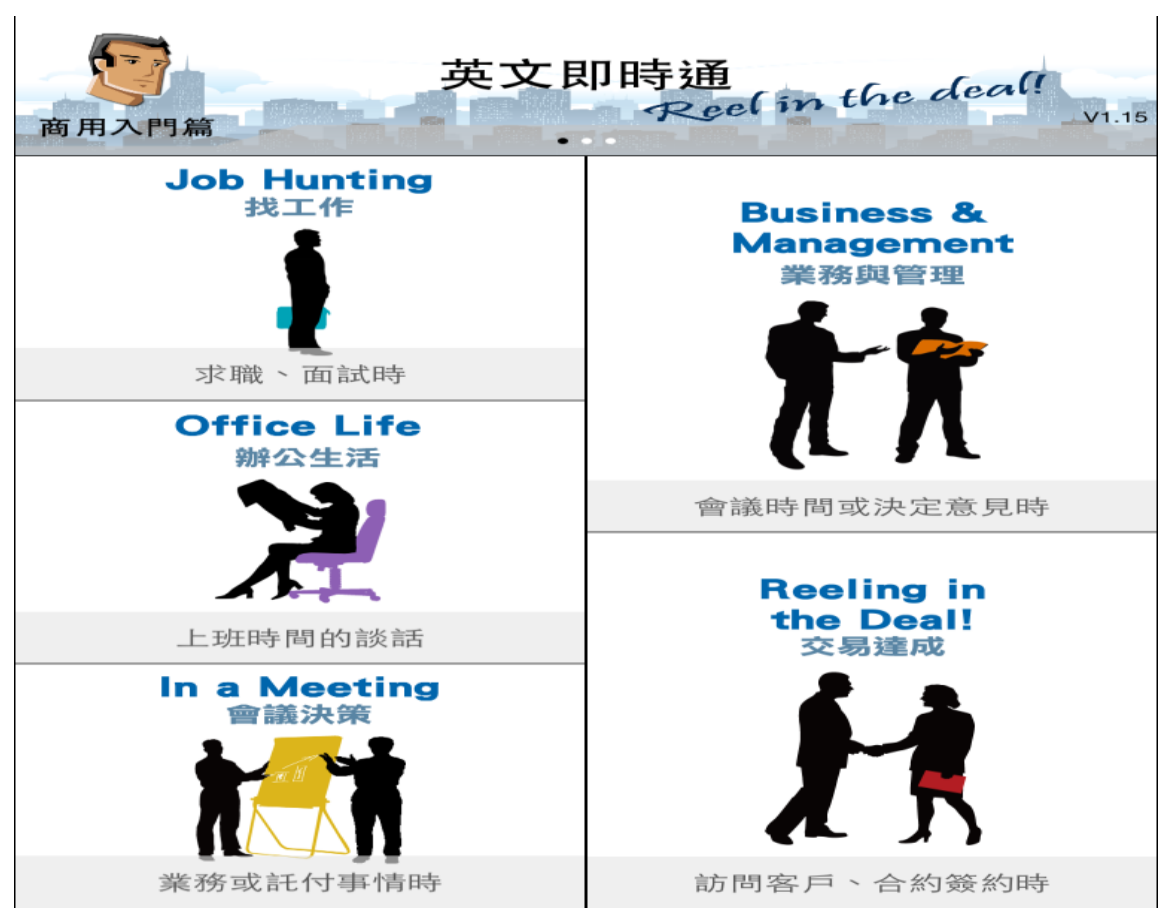

Figure 1. Topics covered in the MALL App 

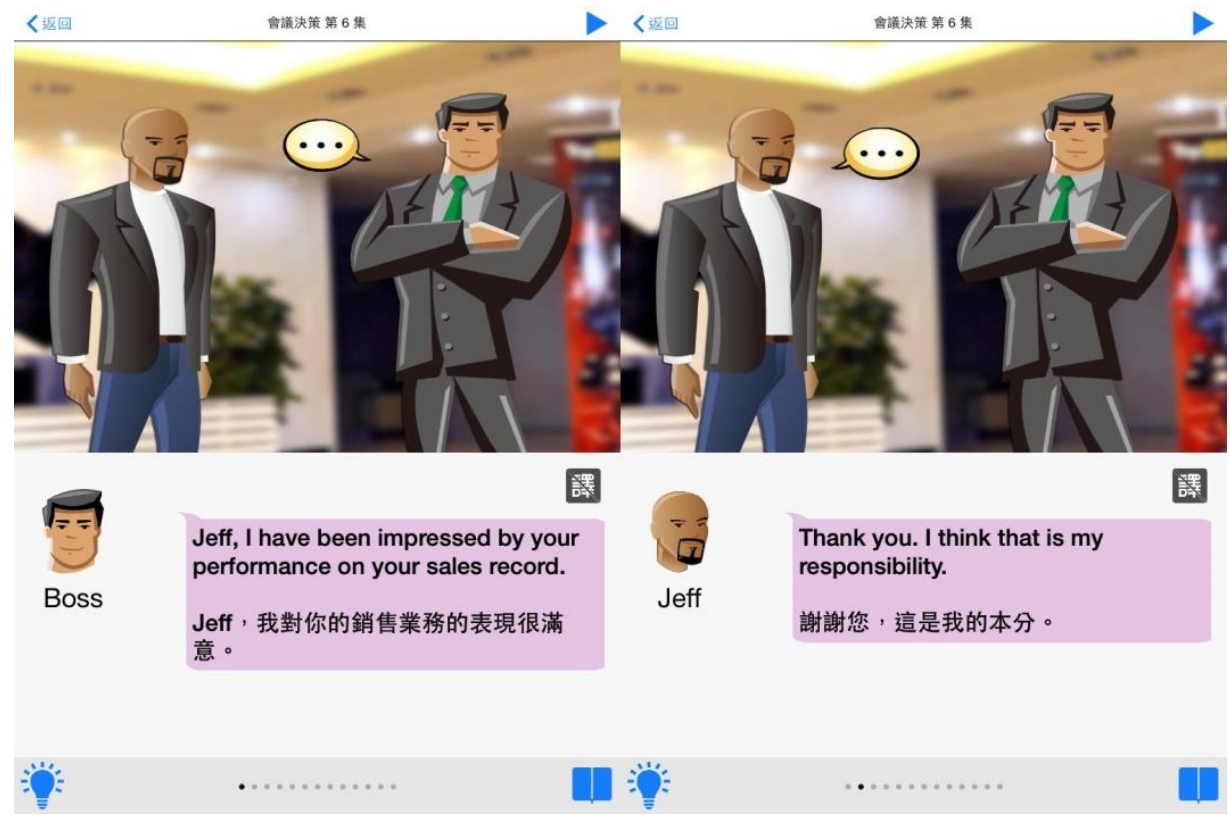

Figure 2. Business English dialogues with Chinese translation

\begin{tabular}{|c|c|}
\hline 戰字一算 & Practical Tips \\
\hline $\begin{array}{l}\text { internship } \\
\text { [intз`n,Jip] } \\
\text { n. 實習 }\end{array}$ & $\begin{array}{l}\text { The Interview } \\
\text { 面試時 }\end{array}$ \\
\hline $\begin{array}{l}\text { I am going to do my internship in the } \\
\text { security company next month. } \\
\text { 我下個月即將要去證劵公司實習。 }\end{array}$ & $\begin{array}{l}\text { When You Go to a Job Interview } \\
\text { 1. It is necessary for you to prepare in advance } \\
\text { the information about the company and the }\end{array}$ \\
\hline $\begin{array}{l}\text { awesome } \\
\text { [osem] } \\
\text { adj. 極好的 }\end{array}$ & $\begin{array}{l}\text { 預先隻備好這間公司職缺的資訊,例如工作內容 } \\
\text { 描述,資格及要求是必須的。 } \\
\text { 2. Get familiar with the route to the place for }\end{array}$ \\
\hline $\begin{array}{l}\text { Michael looks awesome in that } \\
\text { tuxedo. } \\
\text { Michael穿上那件燕尾服非常好看。 }\end{array}$ & $\begin{array}{l}\text { interview and arrive at the place early. } \\
\text { 熟悉路線並提早到達面試地點。 } \\
\text { 3. On the day of interview, remember to be } \\
\text { dressed decently, such as wearing a suit rather }\end{array}$ \\
\hline responsibility & $\begin{array}{l}\text { 面試當天,記得要穿著得體,例如選擇套裝而不是 } \\
\text { T恤配牛仔褲。 }\end{array}$ \\
\hline $\begin{array}{l}\text { [rI, spansə`brlətr] } \\
\text { n. 責任 }\end{array}$ & $\begin{array}{l}\text { 4. Leave a good impression by greeting the } \\
\text { interviewers courteously. } \\
\text { 禮貌的問候面試官以留下好印象。 }\end{array}$ \\
\hline $\begin{array}{l}\text { It is Tom's responsibility to prepare } \\
\text { the documents before the meeting. } \\
\text { 在開會前準備資料是Tom的責任。 }\end{array}$ & $\begin{array}{l}\text { 5. Honesty is the best policy. Do not pretend } \\
\text { you understand everything the interviewers say. } \\
\text { 誠窗為 策。不要假裝你明白面試官所說的一 }\end{array}$ \\
\hline
\end{tabular}

Figure 3. Vocabulary and practical tips

\section{Research Questions}

To find the potential value of mobile devices for improving Taiwanese students' business English listening skills, this study addressed the following questions:

1. Does the language learning environment afforded by mobile media have any effect on the improvement of EFL students' business listening skills? 
2. What are EFL students' experiences, attitudes and perceptions regarding learning business listening skills through the MALL App?

\section{Context and Participants}

The participants in this study were 39 third-year college students (20 males and 19 females aged between 20 and 22 years) from a business English communication course. These students had little or no exposure to spoken English outside their classroom environment. The course aimed to equip the students with the essential English competence needed for business communication. The emphasis was on practicing and improving their listening comprehension skills. Among the students who participated, 17 students with iPhones or iPads were placed in the experimental group, while the remaining 22 students were assigned to the control group.

\section{Instruments}

In this study, research data were collected from pre- and post-tests, weekly quizzes, and an attitude survey. Two listening comprehension tests, designed in parallel, were administered as the pre-test and post-test. Both tests consisted of 25 multiple-choice items for evaluating the students' listening comprehension. Each of the listening comprehension tests was in the form of an audio broadcast. The students were asked to listen to the audio test questions and write their answers down on the answer sheets provided. An experienced English teacher who had previously taught students of the same level verified both tests for content validity. In addition, weekly quizzes covering topics involved in the class materials were distributed to the students over four weeks to examine the learning progress made by the students in listening comprehension. According to Sharples (2009), a useful method for assessing MALL technology is to address its usability, effectiveness, and user satisfaction. Following Sharples's suggestions, an attitude survey questionnaire with a five point Likert-type scale was composed to address the students' perceptions regarding MALL, with a particular focus on the way it was being used, how effective it was, and the level of satisfaction derived. The survey consisted of 25 questions and was reviewed by an English teacher and an information technology expert to ensure the questions were properly phrased and relevant to the study.

\section{Procedures}

The study began with the administration of the pre-test. Subsequently, the participants in the experimental group were given instructions on how to access the MALL App. The instructor was the researcher who developed the MALL App for the project. During the treatment period, students were asked to perform additional listening practices related to the following topics covered in the MALL App: (1) Job Hunting (2) Office Life (3) In a Meeting (4) Business \& Management (5) Reeling in a Deal. The students in the experimental group engaged themselves in a mobile learning environment, where they were allowed to make use of their mobile devices (iPhones and iPads) to practice their listening skills. This allowed them to develop their business English listening capabilities in a more suitable and flexible environment. In contrast with the experimental group, the students in the control group used identical business listening materials, but they were only given computer-assisted language 


\section{Macrothink}

learning. They used a PC, either in the computer lab or at home, to perform the same learning tasks. Chen (2007) indicated that successful listening skills are acquired over time and with a great deal of practice. For this reason, all students were encouraged to listen to the business English dialogues during their spare time. These dialogues focus on various business scenarios in a role-playing format. Each dialogue is followed by a comprehension exercise (see Figure 4), which was designed to build vocabulary, provide listening practice and check understanding. In addition, a weekly quiz on listening was distributed to each of the participating students to examine their learning progress. After five weeks, the participants in both the control and experimental groups took the same post-test to make comparisons between them regarding the improvement in their business English listening comprehension. At the end of the experiment, a survey was conducted to gather feedback from the students who had used the MALL App. Through this survey, the students reported on their attitudes with regards to the mobile learning experience.

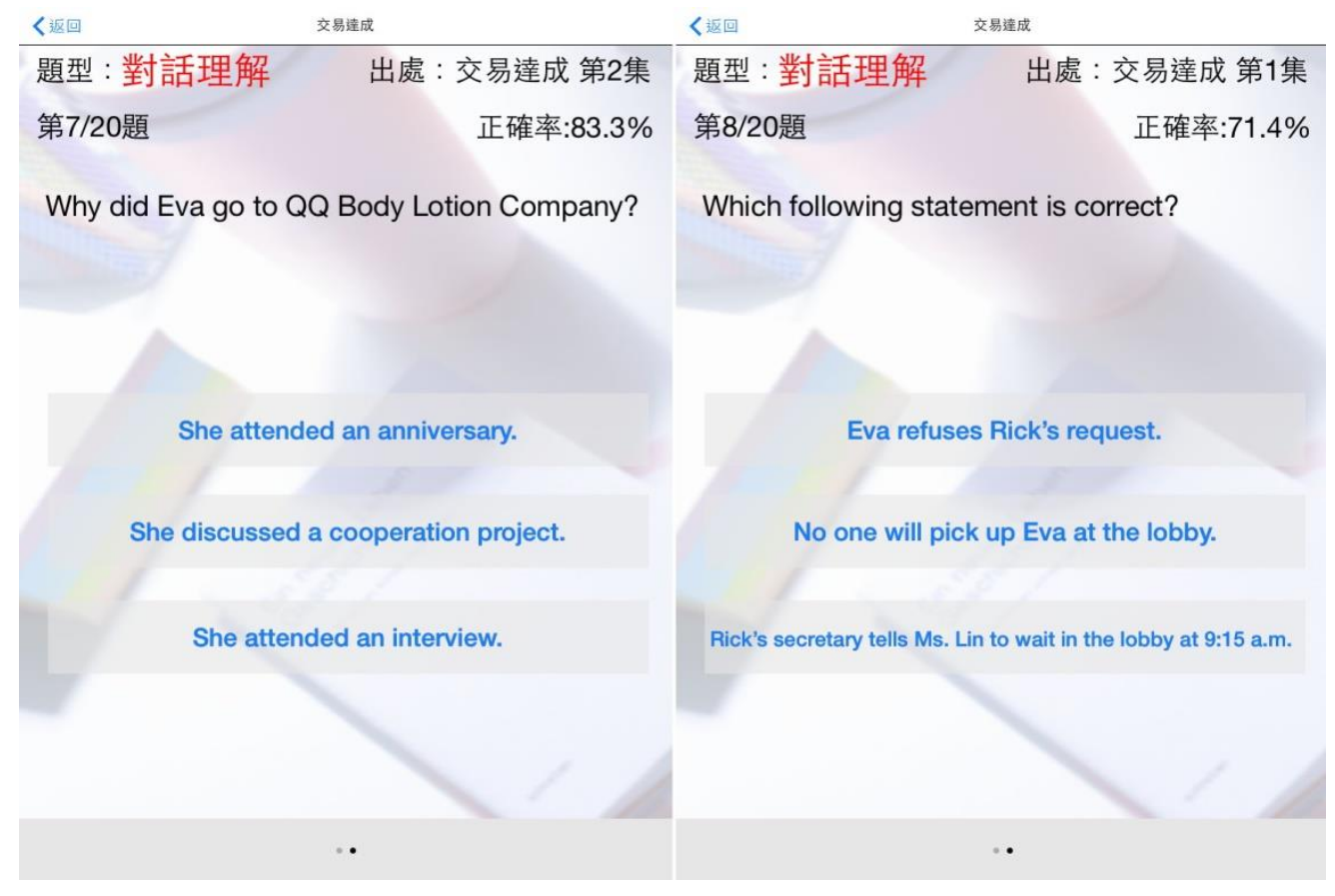

Figure 4. Listening comprehension exercises

\section{Results}

One of the objectives of this study was to investigate the effectiveness of mobile learning on ESP students' listening performance. It was therefore first necessary to ensure that the students in the control group and the students in the experimental group had comparable listening comprehension levels before beginning the treatment. An independent $t$-test was used to test the similarity of the two groups based on their pre-test performances. The results, as shown in table 1, indicated that that there was no significant difference in the average scores of the students in the control and experimental groups $(t=-0.11, p=0.935)$. This is an indication that both groups were at the same competence level in English listening comprehension prior to the learning activities. 
Table 1. Mean scores on the pretest

\begin{tabular}{llllll}
\hline Group & $\boldsymbol{N}$ & Mean & SD & $\boldsymbol{t}$ Value & Sig. (2-tailed) \\
\hline Control & 22 & 65.12 & 5.58 & \multirow{2}{*}{0.11} & \multirow{2}{*}{0.935} \\
Experiment & 17 & 64.56 & 5.22 & & \\
\hline
\end{tabular}

$* * p<0.01$

Research Question 1 - Does the language learning environment afforded by mobile media have any effect on the improvement of EFL students' business listening skills?

In determining whether there was any significant improvement made in the students' business English listening comprehension, a paired sample $t$-test was used to compare the pre-test and post-test mean scores of both groups. Table 2 shows the results for the control group. The results demonstrated that the mean score on the post-test was significantly higher than that obtained on the pre-test $(p<0.01)$. Table 3 shows the paired sample $t$-test results for the experimental group. It can be seen that during the four weeks, the experimental group made remarkable progress in listening comprehension $(p<0.01)$.

Table 2. Mean scores on the pretest and posttest for the control group

\begin{tabular}{llllll}
\hline & $\boldsymbol{N}$ & Mean & SD & $\boldsymbol{t}$ Value & Sig. (2-tailed) \\
\hline Pretest & 22 & 65.12 & 4.83 & \multirow{2}{*}{-9.45} & $0.000^{* *}$ \\
Posttest & 17 & 73.01 & 5.07 & & \\
\hline
\end{tabular}

**p $p<0.01$

Table 3. Mean scores on the pretest and posttest for the experimental group

\begin{tabular}{llllll}
\hline & $\boldsymbol{N}$ & Mean & SD & $\boldsymbol{t}$ Value & Sig. (2-tailed) \\
\hline Pretest & 22 & 64.56 & 5.58 & -10.99 & $0.000^{* *}$ \\
Posttest & 17 & 80.37 & 6.04 & & \\
\hline
\end{tabular}

$* * p<0.01$

The results from both groups showed that students significantly improved their business English listening skills over time. However, the treatment effects were investigated by an analysis of covariance (ANCOVA) on the post-test scores of both groups (see Table 4), which indicated that the experimental group achieved a greater improvement in their business listening comprehension than did the control group. This significant difference can be attributed to the use of mobile devices for the learning tasks.

Table 4. ANCOVA of the posttest results

\begin{tabular}{lllllll}
\hline & Group & N & Mean & SD & F & Sig. (2-tailed) \\
\hline \multirow{2}{*}{ Posttest } & Control & 22 & 73.01 & 5.07 & \multirow{2}{*}{49.68} & $0.000 * *$ \\
& Experimental & 17 & 80.37 & 6.04 & & \\
\hline 0.01 & & & & & &
\end{tabular}

In addition, this study also examined the learning progress of students with regards to their listening comprehension skills during the four weeks. The average test scores of both groups over a one month period are shown in Figure 5. Both groups made progress every week, but 
the experimental group had significantly better results for the tests than the control group, specifically starting at the third week.

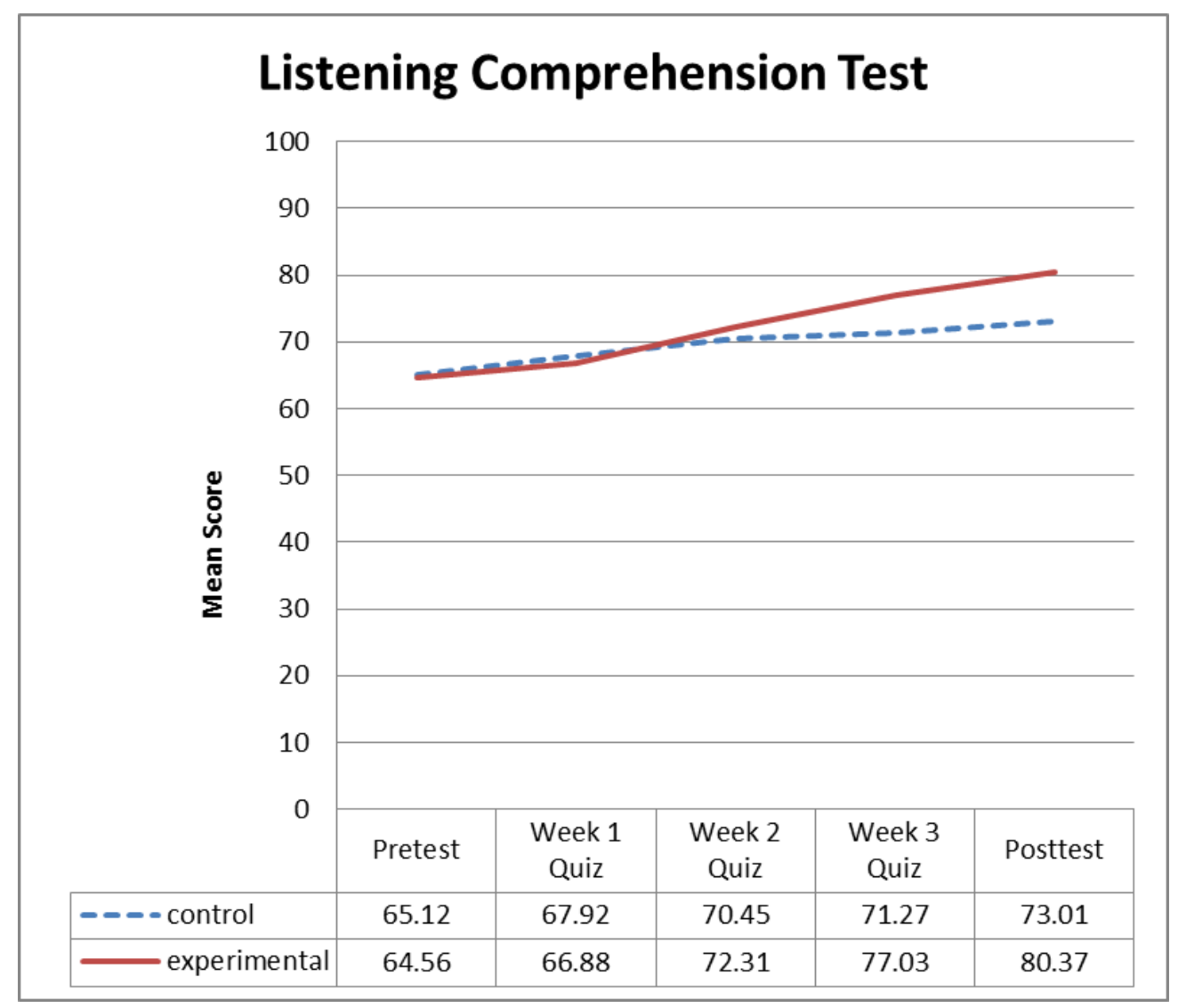

Figure 5. Students' progress in listening improvement

Research Question 2 - What are EFL students' experiences, attitudes and perceptions regarding learning business listening skills through the MALL App?

At the end of the study, the students in the experimental group were asked to express their attitude with regards to the usability and effectiveness of and satisfaction with the MALL instruction. The overall experiences and attitudes, as well as perceptions with regards to the learning method were positive $(\overline{\mathrm{X}}=4.05)$, as shown in Table 5. This indicates that the students had a positive attitude and perception regarding their mobile learning experience, as well as expressing a high acceptance level for this learning approach.

Table 5. Students' attitudes towards the usability, effectiveness, and satisfaction of the MALL App

\section{Statement}

Mean S.D.

\section{Usability}

1. Learning to use the MALL App is easy for me.

2. The MALL App interface design is simple and user-friendly.

3. My interaction with the MALL App is clear and understandable.

$3.89 \quad 0.63$

4. It is easy for me to perform learning tasks when using mobile

$4.22 \quad 0.71$


devices.

5. Overall, I find the MALL App easy to use.

Effectiveness

6. Using the MALL App allows me to take charge of my own

4.12 learning.

7. Mobile devices enable me to accomplish learning tasks anywhere and at any time.

8. Using the MALL App improves my business English-listening 4.06

0.68 performance.

9. Using the MALL App enhances my English vocabulary for 4.130 .79 business.

10. The Chinese translation helps me understand the language better 3.82 and makes listening comprehension easier.

11. The MALL App provides adequate support for business 4.06

English-listening practice.

12. The MALL instruction allows more self-directed learning than traditional classroom instruction.

13. The multimedia effects such as images and audio offer a 4.23 favorable environment for learning English.

14. The MALL App provides useful exercises to improve my 3.94 listening skills.

15. Overall, I find this mobile technology to be a useful tool to support my ESP study.

\section{Satisfaction}

16. I find it interesting to perform learning tasks on the mobile 4.08 devices.

17. I am satisfied with the content and materials offered by the MALL App.

18. I'm willing to continue using mobile devices for foreign 3.79

language learning.

19. I enjoyed the convenience of practicing English on my own 3.96 time.

20. The design and layout of the MALL App is relevant to ESP learning.

21. The MALL App is sufficiently helpful to improve my listening skills for business.

22. The translation support helps reduce language-learning anxiety.

23. Participation in the MALL lessons promotes my motivation to learn English.

24. Using mobile devices as a language tool helps me to cultivate a 3.83 positive attitude towards MALL.

25. Overall, I am satisfied with using mobile devices for learning a $4.03 \quad 0.62$ foreign language. 


\section{Discussion}

This study showed that students who were engaged in the mobile learning environment outperformed those who participated in business English listening tasks without the use of mobile devices. The results indicated that MALL benefited ESP students in the following aspects:

\section{- Increasing confidence and self-motivation}

Convenience is an important factor in motivating students to learn. In this study, students were encouraged to utilize their spare time to participate in ESP-learning tasks. The results showed that students could also learn well outside the classroom setting. Most of the students thought that the MALL App was easy to use and were satisfied with the mobile learning experience. They also perceived such mobile technology-enhanced learning as a useful means of acquiring foreign language knowledge, because it provided them with an opportunity to practice anytime and anywhere, hence learning the English-listening content seemed to be easier and more convenient. This is an interesting finding, because it suggests that regular exposure to authentic listening texts with appropriate tasks can help increase student confidence and make very fast progress.

\section{- Improving student interest and participation}

The students also exhibited a keen interest in learning business English with the aid of their mobile devices and were highly motivated by the unique experience of the educational content, which contains multimedia objects such as images, audio, and texts in podcasts to improve listening skills. For instance, the pronunciation of indigenous words and their Chinese translation can be obtained by just a touch of the screen during the learning activities. These features considerably increased the students' interest in MALL and provided them with a personalized learning experience.

\section{- Enhancing listening abilities}

The results indicated that students in the experimental group demonstrated greater improvement in their listening tests than students in the control group. The significant difference is contributed to the use of mobile devices in the business English listening activities. There are many technological advantages to using mobile devices for listening practices. For example, students always carry their mobile devices so they can review and listen to the materials as many times as they want. Adequate listening practice could give the learners essential contacts with handy input that might trigger their listening performances.

\section{- Increasing vocabulary knowledge}

One other benefit derived from the use of the MALL App was the students' increasing vocabulary knowledge through their participation in the independent listening exercises. The data from this study suggests that successful listening comprehension may be of help in the acquisition of new vocabulary. To successfully communicate in the business environment, the ability to be concise and get straight to the point is greatly appreciated. Having a wide range of vocabulary and the ability to select the right word to describe ideas is an indispensable 
skill set in business English. Indeed, a thorough examination of the relationship between vocabulary knowledge and students' listening comprehension ability will be necessary in future MALL studies.

\section{- Reducing foreign language learning anxiety}

In addition to the opportunities to study various contents, authentic listening materials will raise student awareness of diverse accents of English. By faced with various forms and accent of listening inputs, students will eliminate their frustration on the genuine spoken English. In this study, many of the students indicated that the mobile learning helped reduce the anxiety and frustration they had previously experienced while learning a foreign language. Acquiring listening skills may be frustrating to some students because there are no rules as in grammar teaching (Chen, 2007).With the mobile technology, students were able to learn in their own ways and at the same time, enjoy learning.

\section{- Enabling autonomous learning}

The positive opinion $(\overline{\mathrm{X}}=4.05)$ regarding this type of instruction supported the MALL App design used in this study, which aimed at developing a fast and user-friendly learning environment that could promote autonomous motivation for learning the English language. The data showed that students enjoyed having access to the mobile materials specifically designed to improve their learning performance. Nowadays, EFL learners can easily access language learning environment through the internet and other multimedia. It is necessary for teachers to design programs that enable students to continue learning after instruction has finished. Through mobile learning, students were able to become more involved and take charge of their own learning.

\section{Conclusions}

Listening comprehension is a prerequisite for language acquisition. It requires students to continue learning informally. As students in the non-English speaking countries generally lack exposure to authentic listening contexts, it is important that they are assisted properly in the practice of English listening. This study provided evidence that a mobile device-supported program can provide students with a portable solution that is adaptable and effective to support their ESP listening activities. It also suggested that MALL instruction can reduce listening anxiety and enable students to become autonomous learners.

Although the findings demonstrated an improvement in the listening performance of the participants after four weeks of MALL instruction, there were some limitations that should be addressed in future studies. First, the time period used for the study was too short. It is worth conducting extended studies with a longer trial period. Second, it would be interesting to compare the learning performance of the experimental group with that of students who learn business English with other handheld devices, especially as there is a trend for mobile devices to become a common learning tool in the near future (Norris, Hossain, \& Soloway, 2011). 


\section{Macrothink}

\section{References}

Baleghizadeh, S., \& Oladrostam, E. (2010). The effect of mobile assisted language (MALL) on grammatical accuracy of EFL students. MEXTESOL Journal, 34(2), 1-10.

Chang, C. K., \& Hsu, C. K., (2011). A mobile-assisted synchronously collaborative translation-annotation system for English as a foreign language (EFL) comprehension. Computer Assisted Language Learning, 24(2), 155-180.

Chen, C. M., \& Chung, C. J., (2008). Personalized mobile English vocabulary learning system based on item response theory and learning memory cycle. Computers \& Education, 51(2), 624-645.

Chen, J. C. (2007). Enhancing technology college students' English listening comprehension by listening journals. Journal of Nanya Institute of Technology, 27, 143-160.

Chen, X. B. (2013). Tablets for informal language learning: Students usage and attitudes. Language Learning \& Technology, 17(1), 20-36.

Chinnery, G. (2006). Emerging Technologies - Going to the MALL: Mobile Assisted Language Learning. Language Learning \& Technology, 10(1), 9-16.

Falloon, G. (2013). Young students using iPads: App design and content influences on their learning pathways. Computers \& Education, 68, 505-521.

Franklin, T. (2011). Mobile Learning: At the Tipping Point. Turkish Online Journal of Educational Technology, 10(4), 261-275.

Hsu, C. K., Hwang, G. J., Chang, Y. T., \& Chang, C. K. (2013). Effects of video caption modes on English listening comprehension and vocabulary acquisition using handheld devices. Educational Technology \& Society, 16(1), 403-414.

Kukulska-Hulme, A., \& Shield, L. (2008). An overview of mobile assisted language learning: From content delivery to supported collaboration and interaction. ReCALL, 20(3), 279-289.

Krashen, S. (1981). Second language acquisition and second language learning. Oxford: Pergamon Press.

Lan, Y. J., Sung, Y. T., \& Chang, K. E. (2007). A mobile-device-supported peer-assisted learning system for collaborative early EFL reading. Language Learning \& Technology, 11(3), 130-151.

Li, Z., \& Hegelheimer, V. (2013). Mobile-assisted grammar exercises: Effects on self-editing in L2. Language Learning and Technology, 17(3), 135-156.

Luo, C. P. (2008). An action research plan for developing and implementing the students' listening comprehension skills. English Language Teaching, 1(1), 25-28.

Lynch, T., \& Mendelsohn, D. (2002). Listening. In N. Schmitt (Ed.), An introduction to applied linguistics (pp. 193-210). London: Arnold. 
Moyer, A. (2006). Language contact and confidence in second language listening comprehension: A pilot study of advanced learners of German. Foreign Language Annals, 39(2), 255-275.

Miangah, T. M., \& Nezarat, A. (2012). Mobile-Assisted Language Learning. International Journal of Distributed \& Parallel Systems, 3(1), 309-319.

Nah, K. C., White, P., \& Sussex, R. (2008). The potential of using mobile phone to access the Internet for learning EFL listening skills within a Korean context. ReCALL, 20(3), 331-347.

Nation, I.S.P. \& Newton, J. (2009). Teaching ESL/EFL listening and speaking. New York: Routledge.

Norris, C., Hossain, A., \& Soloway, E. (2011). Using smartphones as essential tools for learning: A call to place schools on the right side of the $21^{\text {st }}$ century. Educational technology, 51(3), 18-25.

Nunan, D. (1998). Approaches to teaching listening in the language classroom. Paper presented at the Korea TESOL Conference, Seoul.

Nunan, D. (2002). Listening in language learning. In J. Richards \& W. Renandya (Eds.), Methodology in language teaching: An anthology of current practice (pp. 238-241). UK: Cambridge University Press.

Peng, H., Su, Y. J., Chou, C. \& Tsai, C. C. (2009). Ubiquitous knowledge construction: Mobile learning re-defined and a conceptual framework. Innovations in Education \& Teaching International, 46(2), 171-183.

Reinders, H. (2010). Twenty ideas for using mobile phones in the language classroom. English Teaching Forum, 48(3), 20-25.

Richards, J., \& Renandya, W. (2002). Methodology in language teaching: An anthology of current practice. UK: Cambridge University Press.

Rubin, J. (1994). A review of second language listening comprehension research. Modern Language Journal, 78, 199-211.

Rost, M. (1994). Introducing listening. London: Penguin.

Rost, M. (2001). Listening. In R. Carter \& D. Nunan (Eds.), The Cambridge guide to teaching English to Speaker of other languages. Cambridge: Cambridge University.

Sharples, M. (2009). Methods for evaluating mobile learning. In G. Vavoula, N. Pachler, \& A. Kukulska-Hume (Eds), Researching Mobile Learning: Frameworks, Tools and Research Designs (pp. 17-39). Oxford, UK: Peter Lang Publishing Group.

Thornton, P., \& Houser, C. (2005). Using mobile phones in English education in Japan. Journal of Computer Assisted Learning, 21(3), 217-228.

Valk, J. H., Rashid, A., \& Elder, L. (2010). Using mobile phones to improve educational outcomes: An analysis of evidence from Asia. International Review of Research in Open and 
Distance Learning, 11(1), 117-140.

Wang, D., Xou, B., \& Xing, M. (2014). Vocabulary Learning and Consolidation with Mobile Application. International Journal of Computer-Assisted Language Learning and Teaching, $4(1), 101-112$.

Wang, Y. S., Wu, M. C., \& Wang, H. Y. (2009). Investigating the determinants and age and gender differences in the acceptance of mobile learning. British Journal of Educational Technology, 40(1), 91-118.

Zhang, H., Song, W., \& Huang, R. (2014). Business English Vocabulary Learning With Mobile Phone: A Chinese Students' Perspective. International Journal of Computer-Assisted Language Learning and Teaching, 4(2), 46-63.

\section{Copyright Disclaimer}

Copyright for this article is retained by the author(s), with first publication rights granted to the journal.

This is an open-access article distributed under the terms and conditions of the Creative Commons Attribution license (http://creativecommons.org/licenses/by/3.0/). 